\title{
Being a black woman conference interpreter in Brazil: an interview with Shanta Walker ${ }^{1}$
}

Interviewed by Luciana Carvalho Fonseca

\section{Introduction}

This is the second of what I suspect will turn out to be a series of interviews with black conference interpreters in Brazil. The first interview came out in Translatio (2017), a translation journal published by the Universidade do Rio Grande do Sul (UFRGS). On the occasion, the journal number was devoted to papers under the theme Translation and Black Diasporas (Tradução e Diásporas Negras). The organizers invited me to contribute by interviewing experienced black Brazilian conference interpreters.

Because of Brazil's segregationist history and due to the almost allwhite profile of Conference Interpreting, I immediately knew that finding people who met the description would be an arduous task. This was confirmed when Dennys Silva-Reis, from the University of Brasília, Christiano Sanches, from the Pontifical Catholic University of Rio de Janeiro, and I spent over a month prospecting black interpreters. Most interpreters we found were not seasoned interpreters. On the other hand, the ones that were professional full-time interpreters either did not identify as black or were reluctant to give an interview on the topic.

I had naively made two assumptions, despite making conscientious efforts to avoid naturalizations to my best in all aspects of life. The first assumption was that the Brazilian qualifier was seemingly straightforward. Therefore, all of the black conference interpreters we contacted were con-

\footnotetext{
${ }^{1}$ I would like to acknowledge Amanda Bittencourt and Isabela Martins, who are two of a young and promising group of racially and gender-aware Translation undergraduate students at the Pontifical Catholic University of São Paulo (PUCSP), for transcribing the interview.
} 
sidered Brazilian without a second thought. To my surprise, the shortlisted did not identify completely with being Brazilian. As recounted in the interviews, their non-Brazilian identity is very marked - and used for protection from discriminatory situations.

My first interviewee was Amaury Williams de Castro (Carvalho Fonseca, 2017), who in addition to being a Brazilian national is also Venezuelan. Williams grew up and has spent most of his life in Spanishspeaking countries, and speaks Spanish as an A language and Portuguese as a B language.

For this number of Tradução em Revista on Interpreting Studies I interviewed Shanta Walker, who is American and moved to Brazil at a very young age, having grown up in an American family between Brazil and the United States. Walker is what interpreting jargon calls a double A: someone who speaks two languages natively or with native-like competence. In her case, English and Portuguese are equally strong.

As a teacher and trainer, I only started witnessing black students of Translation and Interpreting at university level in the last couple of years. The year 2016 was noteworthy because it was the first and only year I had two black women interpreting students in the same class, accounting for approximately twenty percent of the group.

Before I started working at the Pontifical Catholic University of São Paulo (PUCSP), I was an interpreting and translator trainer for nearly a decade at Associação Alumni. The association holds an independent training program and was the first and has been one of the most prestigious translation and interpreting courses in the country. I recall having had one black student at Alumni in a ten-year span.

Due to the underrepresentation of blacks at university level and the resulting lack of general access to all the social privileges that come with a university education - such as speaking a foreign language, attending good schools, paying for language/interpreting courses, or living abroad -, during my entire career as a conference interpreter I had only come across two self-identified black colleagues. 
This brings me to my second primitive assumption: the qualifier $e x-$ perienced, which is excluding of blacks because it bears the weight of white hegemony if we take into account that younger black interpreters have only recently started to enter the profession, mainly through recent access to university.

In the field of higher education, because of educational policies promoted by the Lula and Rousseff Administrations (2003-2016), there has been a marked increase in access rates of lower-income and black students across the country. It is worth mentioning that affirmative action laws only gained momentum in Brazil under the Workers' Party (PT), although they slowly started to appear on the country's agenda under the neoliberal Fernando Henrique Cardoso Administration (1995-2003). Change seemed to be underway with more black students at universities, the majority of which were the first in their family to hold a degree. It is still uncertain whether such policies will be maintained by the current vice-president, Michel Temer, whose approval ratings are worthy of a putschist. However, the black population of Brazil is unlikely to retrocede.

In this social context, Conference Interpreting in Brazil, which has to date been extensively all-white, will certainly witness an increase in diversity. Therefore, the identity issues exploring what it means to be a black interpreter in Brazil, which have largely gone (in)conveniently unnoticed and unexplored, are likely to spring to the surface and will have to be dealt with by the profession.

Williams' and Walker's words enables us - members of the profession - to explore and understand black interpreter identity in Brazil, and to tap our sense of justice and will to promote change.

When Williams' and Walker's interviews are put side by side, one notices that the interviewees have a strong non-Brazilian identity, which both of them use - through their language skills - to protect themselves from discrimination. Another point in common is the mention of the luxury hotels in Brazil as risk zones - or at the very least as potentially hostile spaces - for black interpreters. 
In Brazil, racial segregation is still denied in many circles and at many levels. One instance that stands out is the Rio de Janeiro State Appellate Court, which struck down in 2009 the state's "affirmative action law as unconstitutional with a justification firmly entrenched in the dated notion of Brazil as a racial democracy." (Hernández, 2013, p. 156)

The hegemonic notion that Brazil is a racial democracy derives from a strategically constructed discourse that keeps the country in what Hernández (2013) terms a racially innocent state. According to Hernández, being racially innocent means avoiding the obligation of explicitly addressing race. However, race is undeniably present across Brazilian society:

\begin{abstract}
Afro-Brazilian public figures describe the de facto segregation of Brazil as having a comparable visceral effect to that of apartheid South Africa, where there are two Brazil's - one in the exclusive white hotel areas, and another in the primarily nonwhite favelas and streets. (Hernández, 2014, p. 86) (emphasis added)
\end{abstract}

Black guests rarely occupy Brazilian luxury hotels. Needless to say black women qualified professionals. Being a qualified and educated black woman in Brazil means having to deal with stereotyping and discrimination on a daily basis, as Tolentino (2017) puts it:

\footnotetext{
When it comes to black women, people expect our place to be that of the maid, cleaning lady, general services, nanny, paper picker. Today a woman stopped me on the street and asked if I cleaned houses.

[..]

Haughty and confident, I replied: - No. I'm doing a masters. I'm a teacher.

From her mouth I did not hear another word. I think disbelief and embarrassment stopped her from saying anything else.
}

Throughout the interview, Shanta Walker revealed how she navigates the elitist environments of Conference Interpreting, with a display of diplomacy and spirituality. Her narrative underscores how black interpreters have to deal with age-old and naturalized discriminatory practices in the natural habitat of conference interpreters: luxury hotels, where discrimi- 
nation runs amok in the form of outright mistreatment and inquisitive behavior on the part of hotel staff - who, in turn, are likely to be non-white. According to the unwritten and unsaid rules of Brazilian segregation, Walker is not expected to be there.

Non-black interpreters, on the other hand, are much more unlikely to be asked what they are doing at a fancy hotel, or told they cannot help themselves from the buffet, during a coffee break.

Walker's experience conveyed in this interview raises the readers' awareness to the complexities of being a black woman and belonging to an almost all-white profession frequently occupying almost all-white spaces. Walker is the meeting point of an antinomy. Her locus invites fellow interpreters, groups of interpreters, agencies, and interpreters associations to strive to educate clients on interpreter diversity. Signaling to the market what interpreters look like, who they are, where they come from, might help tear down stereotypes and mitigate the hardship and discrimination faced by black interpreters in the long run. Nevertheless, in the event these skyhigh goals are not accomplished, black interpreters will at least be able to recognize themselves more and feel better represented in the almost allwhite group to which they belong.

\section{Interview}

Luciana Carvalho Fonseca (LCF): First of all nice to meet you, finally! And as you know, I mean finally because Dennys Silva-Reis, from the University of Brasília, Christiano Sanches, from the Pontifical Catholic University of Rio de Janeiro, and I have been prospecting black interpreters to be interviewed for a while. Initially, we had obvious trouble finding you. After we did, most interpreters had ad hoc experience and were not seasoned interpreters. The ones that were professional - mostly full time interpreters either did not identify as black or were not interested in giving an interview on what it is like to be a black interpreter in Brazil. Therefore, secondly, I would like to thank you profusely for your time and willingness.

Shanta Navvab Walker (SNW): True. There are more people here in Brazil that would be identified as black in other countries. 
LCF: I would like to start from the beginning of your career: how did you become an interpreter?

SNW: Like many interpreters, I did not plan to become an interpreter. I started in 1997, almost 20 years now. I was living in Salvador after finishing my major in education and, I am not sure if you have heard about the Bahá'í Faith. They had a project with needy public schools. Do you know the Bahá'í Faith?

\section{LCF: Please enlighten me.}

SNW: The Bahá'í Faith is a religion. The word Bahá'í comes from the Arabic Bahá, glory. There are three core Bahá'í principles: unity of God, unity of religion and unity of humanity. We believe that all religions are manifestations of the one God. It is my religion and at the time the Bahá' were working for poor children in Bahia. I was invited to go to Salvador, since I had just finished my major in Education here, in Brasília. It was a volunteer position. There were many foreigners, and they needed someone to interpret.

The American Consul in Salvador was also Bahá'í; so when there was an event sponsored by the Consulate she asked me to interpret. The Consulate also hired the equipment, and the company that rented out the equipment asked me for my contact, and that is how I started working; one gig led to another. I have been working for almost 20 years.

LCF: Learning on the fly is very common in our profession, it used to be even more common for interpreters who started working about the same time as you and I. At any point did you feel the need for formal training as an interpreter?

SNW: I never did train for interpreting, but I have also worked as a translator, and I recently taught translation at the University of Brasília as a Substitute Professor.

LCF: How long have you been at the University of Brasília? Were you teaching translation and interpreting?

SNW: I was there for three semesters. I started in the beginning of 2015, and my contract ended at the end of the first half of 2016. There were 
several different translation courses in English in the Translation undergraduate course. As you know, as a substitute, you sometimes get to teach a wide range of subjects. I also taught two interesting courses on British Culture and Institutions, and American Culture and Institutions. I am now at the University of Brasília as a graduate. I am taking an MA and translating some of Shakespeare's sonnets into Portuguese.

LCF: Since you started interpreting - successfully - without any training and having become a translator trainer at one of the main public universities in the country, I am guessing you have a very high language competence in both English and Portuguese. Moreover, I have noticed you have pronounced all the Brazilian words you have said so far with native like accent. How and where did you learn your working languages?

SNW: Well, I was born in the U.S. I had learned English as a mother tongue, and Spanish, because we lived in Texas. Then my parents moved to Brazil when I was three, and I learned Portuguese. It was just, you know, growing up and moving.

LCF: You have worked as an interpreter based in more than one state. You mentioned you studied in Brasília and you worked in Bahia, but now you are based in Brasília again. How was the transition?

SNW: It was not bad, actually. I was very fortunate. I had met an interpreter in Bahia who is quite well known. When I mentioned I was moving to Brasília to be close to my family he said he would get in touch with a number of agencies to recommend me. So, when I got here it was not hard to get into the market.

LCF: Thinking about your work as an interpreter and going into the main topic of this interview, have you been discriminated against in the course of work?

SNW: If I said no, I would be lying. At the same time, this is a difficult question to answer because it is always subjective. When you ask a person 'Have you been discriminated?' there are some situations when you clearly say you have been, but since it is subjective too, people may doubt or deny it. I have obviously been discriminated. But I do not feel I have 
been discriminated as an interpreter more than I have in other situations in my life. I might go to an event at a fancy hotel and people might not expect me to be the interpreter, but I cause the same strange reaction walking near my home in a nice neighborhood.

LCF: You mentioned the subjectivity involved in identifying discrimination. Can you think of any examples?

SNW: On some occasions, I have been discriminated in a more objective way; situations which I can really point a finger at what happened. For example, I remember one time I was in Costa do Sauipe translating at an event. As you know, usually interpreters have their meals and go to the coffee breaks with everybody else. However, I have been to a couple of events where I was told that the interpreters could not eat with everybody else. I have even been to an event in which we were not allowed to drink water! My god, right?

\section{LCF: Outrageous.}

SNW: There was one particular event in which all the interpreters were eating during the coffee break, and I went to help myself. The waiter or the security guard, I am not sure who the person was, said I could not eat there. Recently, I was at Costa do Sauípe again and I thought, it is funny because there are a lot of black people at these events. I have been asked there and at other places, usually when I am on my way to grab something to eat, questions like: 'Where are you going?' , 'What are you doing here?'

LCF: You mentioned the waiter or the security guard. Could you tell the position of the people who make you these questions?

SNW: I am not sure exactly what their position was but they were wearing uniform. The woman I mentioned that one time at Costa do Sauípe seemed to have some responsibility because of her attitude and the way she was dressed.

\section{LCF: Do you recall if she was also black?}

SNW: She was lighter-skinned than I, but some people might say she was not black. She had light brown skin. I mean, she was actually quite light, but by her hair you could tell there was some black ancestry.

\section{LCF: Anything else you recall?}


SNW: One time I was sent away from an event. They just did not like my appearance or whatever. They told me they did not need me and a woman, who was completely uncomfortable with the situation, also had to send other interpreters away. They were black too.

\section{LCF: Where did this take place?}

SNW: Here in Brasília.

LCF: Do you get to work with other black colleagues as well on a regular basis in Brasília?

SNW: Not very much. I have actually noticed a change over the years. When I first started, there were no other black interpreters in Salvador that I was aware of. Around 2001 there was Feira Preta in Salvador. It is an organization, an international organization, and they wanted only black interpreters. At the time, the agency I worked for only found me, and the organization found a young man who was not a professional interpreter. We were the two interpreters. They did not find anyone else. Later on, in 2004, I translated at another Feira Preta in São Paulo. They again wanted black interpreters, and the agency was only able to find me and a woman from São Paulo. I do not remember her name. Much more recently, there was an event in Costa do Sauípe - not the one they did not allow me to eat -, which I was hired for because there was going to be a huge feminist event. In the pre-conference program, they would be talking about black feminism. And they wanted all the interpreters to be black women.

\section{LCF: How many other black women interpreters were there?}

SNW: The agency that hired me - for which I have worked for many years - asked me to help find other people. I looked around on Facebook and found another woman from Salvador, there was also one from Porto Alegre and one from Brasília. There was also another lady from Brasília, who is very light skinned. I had never thought of her as black. So between me and the agency we managed to find a few people. However, there was also a male interpreter from Brasília because when we were not able to find enough women, the organizing committee preferred to have a black man instead of a non-black woman. Later, a group of black women interpreters in Brazil was formed in WhatsApp. 
LCF: Tell me more about this WhatsApp group of black interpreters?

SNW: I guess we are maybe six or seven. I believe there are three from Salvador, a young woman interpreter from Brasília, and a man from Brasília as well. In Brasília, I also know two other black interpreters. I guess I know about 10 black people down the hall. This has been a big change, because in the past I did not know anybody even in Salvador, where there were big events and interpreters came from other states. The black interpreter Whatsapp is called Intérpretes Pretas - Black Women Interpreters.

LCF: Do you notice a difference between working in Salvador and in Brasília in terms of racial issues black interpreters may face?

SNW: I do. I did feel there is more discrimination in Salvador. In general, people will treat you differently because you are black. But when they realize you are a foreigner, things change.

LCF: This also came up in the previous interview I held on being a black interpreter in Brazil with Amaury Williams. Do you feel you put on an accent when you speak Portuguese as a mechanism to cope, to adjust, to deal with certain situations?

SNW: I have thought about that. When I was in the conference I mentioned in Costa do Sauípe with that woman. I started to feel irritated, because she kept coming after me with questions about where I was going, what I was doing. She was really treating me with hostility, not like a guest. She was implying that I did not belong there, it was not my place

At one point, I went to the restaurant and a man, the waiter started talking to me, and there were many foreigners, many black foreigners at that event. So, he is talking and I did not answer immediately. I did not really do it on purpose, but he just assumed I did not speak Portuguese. He is speaking English to me, in broken English. He obviously learned a few terms, and I just went with it. I spoke in English with him and in fact the treatment was completely different. I should really do this all the time or put on an accent.

LCF: Putting on an accent and speaking English seem to be very effective mechanisms. They might even fall under the metaphor of lan- 
guage as a weapon. This reminds me of Dwight Bolinger's book Language, the Loaded Weapon (1980). In the case you describe, they would be language weapons in reverse because used against hegemonic forces.

SNW: I guess so. Nevertheless, doing this makes me feel very fake. I have been here in Brazil since I was three.

LCF: I understand. Could we talk a little about your ancestry? Are both of your parents black?

SNW: No, my father is white.

\section{LCF: Are they both American?}

SNW: Yes.

LCF: Could you talk about growing up in a biracial family in the U.S.?

SNW: When I was very little, we still lived in the states. My parents were very much aware of the fact that we were a biracial family. I remember the stories they used to read to me. They used to cut them out from $M s^{2}$ magazine, actually. There was a dialog between a white dad and a black mom. They had a little girl, who would say: 'My dad is white; my mom is black and I am tan.' So they made it playful and natural to tell stories like this one. I was brought up with the ideas that we are all equal. It is one of the principles of the Bahá'í religion as well.

LCF: Having come from an empowering family setting, and having provided in the beginning of this interview a number of examples of discrimination, do you recall the first time you were discriminated because of the color of your skin?

SNW: There is a Bahá'í writing that goes that we are the flowers of a garden, and there are flowers of different colors and the different colors beautify the garden. I think of myself as black, and I think of myself as tan, a mixture of black and white. However, when I came to Brazil, as a child I was discriminated. We lived in Porto Alegre and I was enrolled in a private school. I guess I was the only black girl there and I did not speak Portuguese. Of course, when you are a kid you learn fast, but in the beginning, I had a weird name people could not pronounce. Therefore, they made fun

${ }^{2}$ Ms. is a magazine founded by feminists and social activists Gloria Steinem e Dorothy Pitman Hughes. 
of my name. So it was a combination of factors. This was when I really felt discriminated and realized that the color of my skin had something to do with it. I was a very small child, of 4 or 5 .

When I lived in the States I do not remember feeling discriminated. Even though I was very small, I have memories from when I was two or three, which most people do not. My dad is white, so I have a white grandma, a white grandpa, white cousins. I was closer and I remember spending more time with my dad's family. The way I was raised, no importance was given to the color of a person's skin. It was when I came to Brazil that I had a bit of a hard time, because, in my social class, there were not many black people in Porto Alegre. I was discriminated in school.

LCF: Did this happen throughout your education in Brazil or mostly as a child?

SNW: Until I was almost eleven I felt it more. Afterwards I went to School of the Nations, the International School in Brasília. There were students from all over the world, all colors, so I did not really feel the same way. We lived in Porto Alegre (Southern Region), we also lived in Natal (Northeastern Region), then moved to Vitoria (Southeastern Region). In Vitoria, I did not feel that discriminated, but I had become a bully after the hard time I had in Porto Alegre and Natal. I probably did have a hard time in Vitoria because the other kids were afraid of me.

LCF: Do you recall any other experiences in which skin color played a role?

SNW: I was in the U.S. to spend a year during High School with my aunt on my father's side, and it was interesting. I had a really good time there, but on one or two occasions when I introduced her saying "This is my aunt", people would reply "Oh, but she is not really your aunt, she's... You're just saying that". They would just assume that she could not be my aunt. I found that very strange, and it happened here in Brazil as well.

It is funny because in Brazil, my dad has developed a tan over the years. Eighteen years ago the difference between his skin color and mine was starker. People took notice. Moreover, I remember a person particular- 
ly having a hard time accepting that my grandmother was actually my grandmother. They made questions.

My mother passed away many years ago, and my dad has been married to a black Brazilian woman. I remember we were travelling to a conference in New York many years ago. It took a long time for her to be granted a visa. Every time she applied, they would say, "Look, you're married to an American; if you want to live in the States you should apply for a permanent visa, a green card". She had to keep saying "I don't want to live in the States, I just want to attend a conference!"

On another occasion, my sister was going to the States, and I guess the consular agent at that time turned to her and said "You're not his daughter". At some point we learned that the embassy suspected my dad was smuggling mulattas to the States. It was all despite the fact that, when we came to Brasília - I suppose they do this with all the Americans - they took pictures of us. The pictures in their files were of my dad, my mom, my sister and I. Therefore, they knew who we were and had no real reason to think my sister and I were not my dad's daughters. But color was a big issue in this situation. And this is strange because the U.S. Consul was black herself. So, I have oftentimes been questioned about being my father's daughter. When I started growing up sometimes people though I was my father's girlfriend or wife, so...

LCF: We have talked about discrimination at school, with family members, and at certain venues you were working at as interpreter. How about being discriminated by fellow interpreters? I remember feeling very uncomfortable when a fellow interpreter referred to me as unfair competition, supposedly because I was a young and attractive woman. I felt much belittled. Have you had any negative experience for being a woman - even though ours is a female dominated profession - or for being black?

SNW: Not really, but if the subject [race] comes up I have found that some of them have rather racist views. I cannot say I have personally felt discriminated against by a colleague; however, I feel that when I go places, people in general look at me and treat me in one way, but if I speak 
English or if I say I am an interpreter, the treatment immediately changes. There was a certain interpreter, and I was talking to her once and I got the impression that she kind of had a racist view, but she did not really discriminate against me, that I can say. It was all really subjective, though. Maybe she is not racist in the sense of discriminating, but she seemed very attached to the importance of the skin color. In the black movement, I understand that if you are discriminated - and you usually are -, this acquires social importance. Maybe we just had a bit of a misunderstanding. As I said, it was all really subjective, it wasn't really about "I hate black people".

LCF: I see. Have people ever said to you 'oh, you're not black, you're morena' or something of the kind?

SNW: Sometimes, I ask myself whether I am black or not. If I am not black, I consider myself tan. However, if you ask me if I feel that I am associated with a part of the population that suffers discrimination because of their skin color and characteristics, I will say 'Yes, I do.' Therefore, in this sense, I can say I am black.

I grew up in an environment where skin color did not matter because we were all considered equal and should all get along. If someone says 'you're not black', depending on the situation I might say 'well, but what does it mean to be black?'

I have been discriminated so if I am discriminated this puts me in a category or, in other situations, I might have to say 'Well, you're right, I'm tan.' It depends on the context. I also understand that there are cases that the person is trying to pay me a compliment in a way, or trying to say 'oh, don't worry, it's not as bad as you think...'. The way I react always depends on the situation.

LCF: My last question is what kind of advice would you give a young black interpreter working in Brazil?

SNW: I think I would give general advice on the work environment. I would say that most people are going to be discriminated at some time for one reason or another. Therefore, I think being too defensive is not really healthy. You need to assess the situation. For example, the same situation when someone says 'oh, you're not black, you're morena' might be a good 
opportunity to bring up racial issues and discuss them or might be one that you have to kind of push by. If you have an opportunity to make a point or maybe raise awareness, you can take advantage of it. On the other hand, just try not to take it personally or give it too much attention. Discrimination might be everywhere. Discrimination is more of a universal phenomenon expressed in different ways, in different places. In this sense, because I happen to be here at this time this is what I face. So, if you think about discrimination in a way it does not have to do with who you are, but with how you deal with the situation, it makes it easier. I also think it is important to be very competent at what you do. If you are just as competent as the people who discriminate you, they have an edge.

\section{References}

BOLINGER, Dwight. Language the Loaded Weapon. London \& New York: Routledge, 1980.

FONSECA, Luciana Carvalho. Ser intérprete e negro no Brasil e na Venezuela: entrevista com Amaury Williams de Castro. Translatio, 13, 336-356, 2017.

HERNÁNDEZ, Tanya Katerí. Racial Subordination in Latin America: the role of the state, customary law and the new civil rights response. New York: Cambridge University Press, 2013.

SILVA-REIS, Dennys \& ARAÚJO, Cibele de Guadalupe Sousa (orgs). Translatio, n. 13, 2017.

TOLENTINO, Luana. Questionada se "faz faxina", historiadora negra responde: “Não. Faço mestrado. Sou professora”. Revista Forum. July 18, 2017. http://www.revistaforum.com.br/2017/07/18/questionada-se-fazfaxina-historiadora-negra-responde-nao-faco-mestrado-sou-professora/ Acessed on July 18, 2017.

\section{Abstract}

In this interview, Shanta Walker reveals how she navigates the elitist environments of Conference Interpreting, with a display of diplomacy and spirituality. The interview underscores how age-old and naturalized discrimi- 
natory practices are part of the natural habitat of conference interpreters: luxury hotels. Brazilian luxury hotels are highly exclusive spaces rarely occupied by black women as guests or qualified professionals. Walker is the meeting point of an antinomy. Walker's experience awakens the reader to the complexities of being black and belonging to an almost all-white profession frequently occupying almost all-white spaces.

Keywords: Conference interpreting; Brazil; blackness; women interpreters; racism

\section{Resumo}

Nesta entrevista, Shanta Walker revela como navega, com diplomacia e espiritualidade, os ambientes elitistas da interpretação de conferências no Brasil. Sua fala evidencia como práticas discriminatórias centenárias e naturalizadas integram o habitat natural dos intérpretes de conferência: os hotéis de luxo, espaços altamente exclusivos e raramente ocupados por mulheres negras na condição de profissional qualificada ou hóspede. Shanta é o ponto de encontro dessa antinomia. A entrevista nos desperta para a complexidade de ser negra e pertencer a uma profissão e a ambientes quase exclusivos para brancos.

Palavras-chave: Interpretação de conferências; Brasil; negritude; intérprete; racismo. 